\title{
Associations of Indoor Carbon Dioxide Concentration and Symptoms of Sick Building Syndrome in Air-Conditioned Lecture Halls
}

\section{M Jayasooriya ( $\sim$ varuni.jayasooriya@sjp.ac.lk)}

University of Sri Jayewardenepura https://orcid.org/0000-0003-4130-3019

\section{R M D H Rajapaksha}

university of Sri Jayewardenepura

\author{
A W M Ng \\ Victoria University Faculty of Health Engineering and Science: Victoria University \\ S Muthukumaran \\ victoria university
}

\section{Research}

Keywords: Indoor Air Quality, Indoor Environmental Quality, Sick Building Syndrome, Air Conditioned, Lecture halls, Carbon Dioxide

Posted Date: October 27th, 2020

DOl: https://doi.org/10.21203/rs.3.rs-95698/v1

License: (c) (i) This work is licensed under a Creative Commons Attribution 4.0 International License. Read Full License 


\title{
Associations of Indoor Carbon Dioxide Concentration and Symptoms of Sick Building Syndrome in Air-Conditioned Lecture Halls
}

\author{
Jayasooriya V. $\mathrm{M}^{1}$, Rajapaksha R.M.D.H ${ }^{1}, \mathrm{Ng}$ A.W.M ${ }^{2}$ and Muthukumaran $\mathrm{S}^{2}$ \\ ${ }^{1}$ Department of Forestry and Environmental Science, Faculty of Applied Sciences, University of Sri \\ Jayewardenepura, Nugegoda, Sri Lanka \\ ${ }^{2}$ College of Engineering and Science, Victoria University, Melbourne 14428, Australia \\ Email: varuni.jayasooriya@sjp.ac.lk
}

\begin{abstract}
Indoor Carbon Dioxide $\left(\mathrm{CO}_{2}\right)$ concentrations and its impacts on health and wellbeing of the occupants is a widely discussed topic in building science. Although there is an abundance of knowledge on relationships between the Sick Building Syndrome (SBS) of office environments and naturally ventilated buildings, there is yet a limited knowledge available on associations' of SBS in the students of higher educational facilities especially in air-conditioned lecture halls. To fill this research gap, present study has analyzed indoor $\mathrm{CO}_{2}$ levels of 5 air-conditioned lecture halls with varying occupant densities for ongoing lectures of 2 hours. Statistically significant $(\alpha<0.05)$ strong positive correlation $(R=0.856)$ was shown between the occupant density and the $\mathrm{CO}_{2}$ levels of the selected lecture halls. The results from the ordinal logistic regression shows significant odds ratios $(\mathrm{OR}>1$, at $95 \%$ confidence interval) for the prevalence of symptoms such as headache, difficulties in concentration, dry throat, cough and tiredness/lethargy for certain lecture halls with high occupant densities. The results of the present study highlight the importance of adhering to proper design standards of lecture halls, optimum occupant control and selection of efficient air conditioning systems to maintain the health and wellbeing of higher education students.
\end{abstract}

Keywords: Indoor Air Quality, Indoor Environmental Quality, Sick Building Syndrome, Air Conditioned, Lecture halls, Carbon Dioxide 


\section{Introduction}

In the current practice of building design, Indoor Air Quality (IAQ) has identified to be one of the fundamental indicators of the assessment of healthy living and wellbeing of building occupants in long term (Ern Jun et al., 2017, Patnaik et al., 2018, Licina et al., 2019). Nowadays, air conditioning has become an essential feature in buildings to maintain thermally comfortable indoor conditions during working hours (Mustapa et al., 2016, Sun et al., 2019). Accordingly, people spend $60 \%-90 \%$ of their lifetime in buildings, which is accelerating with the various demands of modern world (Yang et al., 2009, Norhidayah et al., 2013, Antoniadou and Papadopoulos, 2017). A higher education student spends 3-8 years average inside an institutional building during the course of their study. Thus, it is of a greater importance to maintain healthy comfortable indoor environments as it will affect the health, productivity and satisfaction of the students (Heath and Mendell, 2002, El Asmar et al., 2014, Ricciardi and Buratti, 2018)

As building designs trend towards energy efficiency to meet increasing demand of reduced energy consumption in buildings, the importance of indoor IEQ is potentially being neglected. Poor Indoor Environmental Quality (IEQ) has been identified by researchers as a public health issue for years, which leads to widely publicized problems known as Sick Building Syndrome (SBS) and Building-Related Illness (BRI) (Yatim, 2002, Shahzad et al., 2016, Ghaffarianhoseini et al., 2018, Sun et al., 2019). IEQ could be further explained through four major environmental aspects namely Thermal Comfort (TC), Indoor Air Quality (IAQ), Acoustic Comfort (AC) and Visual Comfort (VC) (Oral et al., 2004, Corgnati et al., 2007, Mihai and Iordache, 2016). There are several indicators used in literature to assess IEQ considering these aspects. Among these four major aspects of IEQ, IAQ has been identified as 
a factor that has a significant impact on the prevalence of SBS symptoms on the occupants (Apte and Erdmann, 2002, Gupta et al., 2007, Norhidayah et al., 2013).

Complaints on discomforts and health impacts at non industrial workplaces were reported since late eighties where occupants started to notice various symptoms due to prolonged stays in the buildings (Skov et al., 1990, Wijerathne et al., 2019). BRI and SBS are the most frequently discussed sicknesses that are associated with the buildings which can be rectified through proper design and maintenance of buildings (Mainka and Zajusz-Zubek, 2015, Mentese and Tasdibi, 2016). Moreover, some of the building related diseases include infectious diseases spreading from building services such as Legionnaires' disease and diseases spreading from worker to worker within a building, such as viral infections, that cannot be specifically attributed as diseases that occur due to the poor design of the buildings (Burge, 2004).

World Health Organization defines SBS as a syndrome that comprises with a collection of nonspecific symptoms including eye, nose and throat irritation, mental fatigue, headaches, nausea, dizziness and skin irritation, which is linked with occupancy of certain workplaces (Hedge et al., 1996). According to Gupta et al. (2007), SBS is a set of sub clinical symptoms with no identified causes with most common symptoms identified as irritation in the eyes, blocked nose and throat, complaints in upper airways, headache, dizziness, and sensory discomfort from odors, dry skin, fatigue, lethargy, wheezing, sinus, congestion, skin rash, irritation and nausea. Furthermore, Fisk (2009) states that, several studies assess SBS with the health symptoms such as eye, nose or throat irritation, headache and fatigue. Moreover, SBS is used to describe a situation in which the occupants of a building experience acute health or comfort related effects that seem to be linked directly to the time spent in the building (Joshi, 2008). According to the definition of International Labor Organization, SBS is a phenomenon that occurs when $20 \%$ of the respondents report symptoms associated with their respective location of work in specific association with the air quality (Norhidayah et al., 2013). 
Acceptable IAQ refers to the "air in which there are no known contaminants at harmful concentrations as determined by cognizant authorities and with which a substantial majority (80\% or more) of the people exposed do not express dissatisfaction" (Antoniadou and Papadopoulos, 2017). Wijerathne et al. (2019) state that IAQ is affected by additional parameters apart from the air pollutants which could be attributed to temperature, humidity, odor, harmful biological contaminants and chemicals in the conditioned space. Furthermore, according to Bluyssen (2009), IAQ can be explained by two view points as human point of view and indoor air point of view. Based on the human point of view, IAQ refers to the physical impacts through the exposure to the indoor air as experienced by people who visited or occupied the particular indoor space. The indoor air point of view of IAQ is often expressed as in terms of the rate of ventilation or concentration of specific compounds with the indoor environment (Bluyssen, 2009). Muhamad-Darus et al. (2011) define that "indoor air quality as a term referring to the air quality within and around buildings, especially being its relation to health and productivity of its occupant" (Putra, 2015).

Although there are other pollutants which characterize IAQ condition, indoor $\mathrm{CO}_{2}$ concentration and ventilation rate are commonly used a surrogates and indicators for air quality of indoor environments (Mainka and Zajusz-Zubek, 2015, Ricciardi and Buratti, 2018). Several studies have focused on the measurement of $\mathrm{CO}_{2}$ concentrations as an indicator of indoor air quality (Pereira et al., 2014, Antoniadou and Papadopoulos, 2017, Vilčeková et al., 2017). According to the American Society of Heating, Refrigerating and Air-Conditioning Engineers (ASHRAE) standard, 1000ppm of $\mathrm{CO}_{2}$ concentration is considered as the acceptable level for indoor environment (ASHRAE, 2007).

$\mathrm{CO}_{2}$ is a gas without a color and odor where humans continuously exhale $\mathrm{CO}_{2}$ formed in their body during metabolic processes. If there is no fuel burning, these emissions can contribute highly for the elevated indoor $\mathrm{CO}_{2}$ concentrations (Jones, 1999). According to the Occupant 
Health and Safety (OHAS) (2016) guidelines, there are six $\mathrm{CO}_{2}$ concentration limits which generates different levels of potential health problems. Typical acceptable $\mathrm{CO}_{2}$ concentration level for the occupied space is 350-1000ppm (OHAS, 2016). Furthermore, according to National Institute of Standard Technology (2001) standard, $\mathrm{CO}_{2}$ concentration for the occupied space is $1000 \mathrm{ppm}(1800 \mathrm{mg} / \mathrm{m} 3)$ (Emmerich and Persily, 2001). In addition to that, the recommended value for 8 hour averaged $\mathrm{CO}_{2}$ concentration in indoor environment is $1000 \mathrm{ppm}$ according to the ASHRAE guidelines (ASHRAE, 2007). According to Seppanen and Fisk (2004), metabolism of building occupants is the indoor source of $\mathrm{CO}_{2}$ and outdoor $\mathrm{CO}_{2}$ concentration is moderately constant while it varies depending on the location and probably in the range of 350-450ppm. Human wellbeing and capacity to concentrate was recorded to be declined when $\mathrm{CO}_{2}$ concentration in the air is increasing up to $3000 \mathrm{ppm}$ and $\mathrm{CO}_{2}$ was considered as an indicator of other pollutants in the air (Seppänen et al., 1999). According to Seppanen and Fisk (2004), the $\mathrm{CO}_{2}$ concentration depends on number of occupants, and duration of occupancy, ventilation rate, and room volume.

According to Seppänen et al. (1999) and Erdmann and Apte (2003) there was a positive association between increased $\mathrm{CO}_{2}$ concentration with the prevalence of SBS symptoms which was proven by one-half of 22 studies of SBS symptoms in office buildings. There was a significant association between increasing $\mathrm{CO}_{2}$ levels and SBS symptoms in seventy percent of studies conducted for mechanically ventilated and air conditioned buildings (Erdmann and Apte, 2003). Furthermore, Erdmann et al. (2002) and Apte et al. (2000) found that there are statistically significant differences between $\mathrm{CO}_{2}$ levels and some of SBS symptoms such as sore throat, irritated nose, combined mucous membrane symptoms, tight chest, and wheeze. The adjusted odds ratios for these symptoms ranged from 1.2 to 1.5 per 100 ppm increase in CO2 according to an analysis done for the US office buildings (Apte et al., 2000). Hedge et al. (1996) identified that prevalence of SBS symptoms was high in workers of air conditioned 
settings than naturally ventilated buildings. Moreover, the office workers were the mainly affected community by SBS as they worked in the same place for longer durations. According to Redlich et al. (1997) and Wijerathne et al. (2019), SBS symptoms occur more in airtight buildings than old naturally ventilated buildings. Seppanen and Fisk (2004) state that SBS prevalence is significantly high in air-conditioned buildings than in buildings with simple mechanical ventilation and no humidification, in two of the three analyses in a single study .

Apart from these findings, most of the studies in literature assess the IAQ and thermal comfort in schools, laboratories and other educational facilities in air conditioned and naturally ventilated conditions (Scheff et al., 2000, Katafygiotou and Serghides, 2014, Nico et al., 2015, Chew et al., 2015, Zaki et al., 2017). However, limited studies have been conducted on assessing the relationships between SBS and IAQ of air conditioned lecture theaters where there are unpredictable occupancy patterns (Fu et al., 2019, Kraus and Nováková, 2019). Furthermore, majority of the previous studies have focused on determining relationships between indoor $\mathrm{CO}_{2}$ concentrations and SBS of office workers but there is a limited focus on the impacts of IAQ on the SBS of students of the higher education facilities (Lim et al., 2015, Chirico et al., 2017, Shin et al., 2018). At present, naturally ventilated lecture halls are transformed into air conditioned lecture halls due the long term thermal comfort conditions required for the students (Fang et al., 2018). However, there lies a greater challenge in designing for the proper IAQ of lecture halls due to the unpredictable nature of population density in such facilities. There are no benchmarks to identify standard numbers of students to be assigned for lecture halls based on the physical parameters of the indoor environment such as the floor area and volume of the hall (Majewski et al., 2018). Especially, in many higher educational facilities, student distribution highly varies with size of the lecture halls and the improper management of the occupant density can result in poor IAQ. As a result, this can lead to sicknesses such as SBS that can further lead to prolonging conditions such as BRI (Norbäck 
and Nordström, 2008). Thus, it is important to have an idea about the IAQ of lecture halls and its associations with SBS which could provide insights on improving the comfort conditions and reduce the prevalence of such symptoms. Therefore, this study will aim on identifying the associations between IAQ and SBS symptoms of air conditioned lecture halls by considering indoor $\mathrm{CO}_{2}$ levels as an indicator.

\section{Methodology}

To assess indoor $\mathrm{CO}_{2}$ levels and its associations with SBS, five air conditioned lecture halls of variable dimensions were selected from the Faculty of Applied Sciences, University of Sri Jayewardenepura, Sri Lanka as a case study. The selected lecture halls consisted with windows which were completely closed during the duration of the experiments and the split type air conditioners were under operation. Furthermore, the selected lecture halls comprised with wooden desks, chairs, projector and a computer apart from the air conditioning units. Air conditioners were operational throughout lectures in selected lecture halls and were shut down after the completion of lecture in order to save the energy. Figure 1 shows the dimensions and the orientation of student seating of the five selected lecture halls. The orange color lines show the seating arrangement of the lecture hall and seating area of the students. Green color box indicates the $\mathrm{A} / \mathrm{C}$ machine. $\mathrm{W}$ and $\mathrm{D}$ indicate window and door respectively. For the interpretation of results, lecture halls were given ID's as L01, L02, L03, L04 and L05. These IDs will be used to describe the results and discussion of the study, in the forthcoming sections.

\section{$<$ Figure 1>}

\subsection{Experimental Set up and Data collection}

Continuous $\mathrm{CO}_{2}$, relative humidity $(\mathrm{RH})$ data loggers (Perfect-Prime $\mathrm{CO} 2000$ ) were used to measure indoor and outdoor $\mathrm{CO}_{2}$ concentration, temperature and $\mathrm{RH}$. The data collection was 
conducted for six months from July 2018 to January 2019. Three replicate experiments were conducted for each of the locations within the lecture hall and for the control (when there were zero occupants and air conditioner is not operating while all the windows and doors of the room were widely open). Another experiment was carried out to measure the outdoor ambient $\mathrm{CO}_{2}$ levels, temperature and $\mathrm{RH}$ in the immediate surroundings.

Experiment was set up before the beginning of the lecture and was continued till the end of the lecture when doing the experiment for measuring IAQ. Most of the lectures were carried out for two hours while some of the lectures were carried out for one hour. Data loggers were set up in the height of $1.1 \mathrm{~m}$ to get the measures in occupant zone of a seating person. (Mustapa et al., 2016). There were 3 sampling stations inside the lecture all as front, middle, and back of a lecture hall as indicated in Figure 1.

A questionnaire survey was distributed among the students who attend the lectures in the selected halls to identify the prevalence of SBS symptoms. The occupants who were selected in this study were in between 20-25 age class and they were asked to mention whether they were in good health condition or suffering from prolonged diseases. The occurrences of SBS syndrome symptoms(blocked or stuffy nose, cough, difficulties in concentration, dry throat, dry/itching/ irritated skin, dryness in the eye, fatigue/lethargy/tiredness, headache, heavy headed, itchy or watery eye and nausea/dizziness), type of clothing, satisfaction on the quality of the lecture hall, were assessed during the questionnaire. Sample sizes for L01, L02, L03, L04 and L05 are 56, 52, 61, 48 and 35 respectively (Based on the average number of students attend for each lecture in the series). Daily attendance of students during each lecture series was taken to assess whether there are any correlations between the occupant density and recorded $\mathrm{CO}_{2}$ concentrations. 


\subsection{Statistical Analysis}

Continuous data loggers were set up to record $\mathrm{CO}_{2}$ concentration, ambient temperature and the RH data with 1 second time steps to obtain more precise data and to identify the variations of the $\mathrm{CO}_{2}$ levels with the time. However, for the ease of statistical data analysis, moving average values of the recordings were used to obtain the relationships between $\mathrm{CO}_{2}$ levels and SBS (Tsai et al., 2012, Mustapa et al., 2016). The 15 minute moving averages were obtained for indoor environment as well as for the respective outdoor environment. Differences in $\mathrm{CO}_{2}$ concentration and $\mathrm{RH}$ relative humidity were estimated since there were momentous difference between indoor and outdoor environment and the difference between the indoor and outdoor values were used as a metric for the data analysis. One-way ANOVA was performed at 95\% confidence interval to determine the significant differences in $\mathrm{CO}_{2}$ concentration, $\mathrm{RH}$ and temperature in 3 positions (front, middle, back) in each lecture hall. Tukey's Honest Significant Difference tests were conducted to determine whether there are significant differences of $\mathrm{CO} 2$ concentrations in the positions (front, middle and back) of the lecture halls. Bivariate Pearson correlation tests was performed to identify the relationships between occupant density and indoor $\mathrm{CO}_{2}$ levels. Ordinal Logistic Regression was used to assess the prevalence odds ratios (OR) of reporting a particular SBS syndrome for the selected lecture hall.

\section{Results and Discussion}

\subsection{Indoor carbon dioxide levels of the lecture halls}

Five lecture halls were selected by considering the availability of two hour ongoing lecture series and the data was recorded continually for a semester. The prevalence of SBS was assessed through 11 symptoms which were commonly identified in literature. The lecture halls selected for the study consisted with split type air conditioners. The recorded $\mathrm{CO}_{2}$ levels were compared against the ASHRAE, the currently accepted international standard is for the IAQ. 
Based on the ASHRAE standard, average $\mathrm{CO}_{2}$ concentration should be less than $1000 \mathrm{ppm}$ for 8 hours' time period. The time series for indoor $\mathrm{CO}_{2}$ concentration for the control experiment and the experiment for the front, middle and back of L01 is shown in Figure 2. Summary results obtained for the parameters $\mathrm{CO}_{2}$ concentration, $\mathrm{RH}$ and temperature for the lecture hall and summary statistics for the lecture halls are shown in Tables 1 and 2 respectively. The data obtained for immediate outdoor environment of the lecture halls are shown in Table 3. The lecture halls L01 and L02, and, L03 and L04 were located in close proximity to each other and therefore, a single data set was recorded for above lecture halls in regard to the outdoor $\mathrm{CO}_{2}$ levels.

\section{$<$ Figure $2>$ \\ $<$ Table 1> \\ $<$ Table 2> \\ $<$ Table 3>}

As shown in Figure 2, the $\mathrm{CO}_{2}$ concentration at the beginning is around 500ppm, which is well below the ASHARE standard and continues to be increasing when the lecture progresses. Moreover, the differences are evident in $\mathrm{CO}_{2}$ levels of the control and the lecture due to control conditions where experiment was done by opening all the windows and doors, with optimum natural ventilation. The $\mathrm{CO}_{2}$ concentrations were almost constant during the 2 hour recording period for all three positions. The $\mathrm{CO}_{2}$ concentration in unoccupied scenario for all lecture halls were less than 500ppm. Within the first half an hour of the lecture, the $\mathrm{CO}_{2}$ concentrations in the lecture halls tend to go beyond the ASHRAE standard and keeps on increasing (Figure 2). Similar trends were reported for the other four lecture halls. 
Based on the results during lecture, the $\mathrm{CO}_{2}$ concentration has exceeded 1000ppm which is recommended by ASHRAE for indoor air quality in each of the lecture hall. One of the reasons for elevated $\mathrm{CO}_{2}$ concentration beyond ASHARE standard would be the poor occupant density control for the selected lecture halls. Some of the lecture halls were quite small in dimensions however, were occupied with full capacity at certain lectures during the data collection. Since there are no standards in assigning students for a particular lecture hall and varying dimensions, $\mathrm{CO}_{2}$ levels could vary from one lecture hall to another. The main source of generation of $\mathrm{CO}_{2}$ is respiration of occupants where the concentration is maintained by the ventilation system. L02 recorded the maximum $\mathrm{CO}_{2}$ concentration compared to other lecture halls. The occupant density in L02 is $0.380 \mathrm{~m}^{-2}$ and is highest occupant density among the 5 lecture halls compared.

The results of the present study showed similar trends with the studies done in different regions in the world where the indoor $\mathrm{CO}_{2}$ levels were comparatively high when compared with ASHRAE standards. A study done by Pereira et al. (2014) reported $\mathrm{CO}_{2}$ concentrations above 5000 ppm in some secondary class rooms in Portuguese. This study focused on two class rooms where maximum recorded $\mathrm{CO}_{2}$ concentrations were $6223 \mathrm{ppm}$ and $7645 \mathrm{ppm}$. In addition, the $\mathrm{CO}_{2}$ levels exceeded $1000 \mathrm{ppm}$ in Slovakia classrooms according to the study done by Vilčekováa et al. (2017). In the present study, the recordings of the parameters were taken in 3 positions in the lecture hall as front, middle and back. There were significant differences from one position to another. The one way ANOVA and Tukey Post-Hoc tests showed that $\mathrm{CO}_{2}$ and $\mathrm{RH}$ are significantly different $(\mathrm{p}<0.05)$ for the three positions in each lecture hall. These variations could be visible mainly due to the distribution of the occupants in the classroom. RH has also displayed variations within various locations of the classroom which shows a similar trend to a study by Ellis (2010). 
As per the results shown in Table 1 with 15 minutes moving average values for two hour duration, L01 shows the minimum average $\mathrm{CO}_{2}$ concentration of $759 \mathrm{ppm}$ and $\mathrm{L} 02$ shows the maximum average value of 3428 ppm since the occupant density of L02 is higher than L01. Meanwhile, the recorded maximum RH value is $68.25 \%$ and it was recorded in L04. Minimum $\mathrm{CO}_{2}$ concentration and $\mathrm{RH}$ levels recorded were $759 \mathrm{ppm}$ and $46.19 \%$ for L01 and L02 respectively. Figure 3 shows the box and whiskers plot for distribution of $\mathrm{CO}_{2}$ concentrations and the RH for five lecture halls. According to the Figure 3, L02 has the highest recorded values of both maximum and minimum $\mathrm{CO}_{2}$ levels. The reason for this observation could be the high occupant density of L02, compared to the other lecture halls. L02 shows the lowest maximum and minimum average value for $\mathrm{RH}$.

\section{$<$ Figure 3>}

\subsection{Associations with SBS}

The questionnaire survey consisted with a five-point Likert scale where the students were asked to rate the intensity of symptoms if they feel any of the selected SBS symptoms during the lecture. To obtain the statistical relationships between the indoor $\mathrm{CO}_{2}$ levels and the SBS, following matrices were developed by adapting the matrices developed by Apte et al. (2000) to assess the prevalence of SBS syndrome in office workers.

dCO2 = indoor maximum 15 minute moving average of CO2 level - Outdoor maximum 15 minute moving average of CO2 level

$d R H=$ indoor maximum 15 minute moving average of $R H$

- Outdoor maximum 15 minute moving average of $R H$

Pearson correlation tests were conducted to measure the relationship between $\mathrm{dCO}_{2}, \mathrm{dRH}$ and the occupant density. According to the results, there is a strong positive co-relation between occupant density and $\mathrm{dCO}_{2}(0.925)$ and has shown a statistically significant difference 
$(\mathrm{p}<0.05)$. However RH did not show a significant difference though it showed positive correlation with the occupant density. An ordinal logistic regression was performed for each of the lecture hall to assess the significance of the prevalence of SBS syndromes based on the results of the questionnaire survey. The odds ratios were calculated in reference to the symptom nausea/ dizziness for each of the lecture hall to identify the significance prevalence of various symptoms for each of the lecture hall. An odds ratio (OR) is a measure of association between an exposure and an outcome. The OR represents the odds that an outcome will occur given a particular exposure could be explained as following three phases (Szumilas, 2010).

OR>1 Exposure associated with higher odds of outcome

$\mathrm{OR}=1$ Exposure does not affect odds of outcome

OR $<1$ Exposure associated with lower odds of outcome

At the $95 \%$ Confidence Interval, $(\mathrm{CI})>1$ and $\mathrm{OR}>1$, the prevalence of a symptom for a particular lecture hall is considered to be statistically significant (Zamani et al., 2013). Table 4 shows the summary results of the ordinal logistic regression conducted for five lecture halls in reference to symptom nausea/dizziness. Table 5 shows a summary of $\mathrm{dCO}_{2}, \mathrm{dRH}$ and recorded statistically significant SBS symptoms for each of the lecture hall.

$<$ Table $4>$

$<$ Table $5>$

The results of the ordinal logistic regression shows that headache and cough were statistically significant in $\mathrm{L02}(\mathrm{OR}>1, \mathrm{p}<0.05)$ while headache and difficulties in concentration are 
statistically significant in L01.The prevalence of the symptoms such as difficulties in concentration, dry throat, dryness in the eye and headache were significant in L03 and there were no significant SBS symptoms recorded in L04. Dry throat symptom was statistically significant in L05. Gupta et al. (2007) found a strong positive linear relationship between $\mathrm{CO}_{2}$ concentration and SBS $\left(\mathrm{R}^{2}=0.9499\right)$ in a multi-story centrally air-conditioned airport building in the Delhi City. A study by Erdmann et al. (2002), shows that there is an association between elevated $\mathrm{CO}_{2}$ levels and increase in mucous membrane symptoms and lower respiratory symptoms.

RH levels recorded were within the recommended range for every lecture hall and within the standard thermal comfort conditions. Although RH falls within the standard range (30\%-60\%), there were some visible fluctuations due to uneven nature of the air conditioner operation in lecture halls. Most of the students tend to switch off or increase the temperature level of air conditioner based on their comfort levels. According to a study done by Katafygiotou and Serghides (2014), RH of the class rooms in Cyprus lied within the standard range in all of their seasons.

Although the indoor conditions of L04 were visibly poor compared to other lecture halls, there were no statically significant SBS symptoms recorded for this lecture hall and this could be due to the lower gap between the $\mathrm{CO}_{2}$ and $\mathrm{RH}$ difference compared with the other lecture halls. Similar outcomes were recorded by the studies of Tsai et al. (2012)and Erdmann et al. (2002). According to study Tsai et al. (2012) prevalence of some SBS syndromes were evident even with the lower $\mathrm{CO}_{2}$ concentrations below the maximum limit of ASHRAE guidelines. 


\section{Summary and Conclusions}

Poorly designed buildings and uncontrolled occupancy rates can create various building related health problems for the building occupants. SBS is one such health issue where occupants feel various discomforts during the time they spend inside the building however diminishes when they leave the building. It has been found that indoor $\mathrm{CO}_{2}$ levels play a major role on the prevalence of SBS in buildings. However, several studies in the literature has focused on the office workers and SBS, and limited numbers of studies assessed the impacts for the students in higher educational facilities on SBS. To fill this research gap, present study has selected five air conditioned university lecture halls with varying dimensions and occupant densities as a case study to assess the relationships between indoor $\mathrm{CO}_{2}$ levels and prevalence of SBS symptoms.

According to the results reported, the $\mathrm{CO}_{2}$ concentration has exceeded $1000 \mathrm{ppm}$ for each lecture hall, which is the recommended ASHRAE standard for the indoor air quality. Proper occupant control could pay a major role in maintaining the standard indoor $\mathrm{CO}_{2}$ levels within lecture halls. The main source of generation of $\mathrm{CO}_{2}$ inside the lecture halls is through the respiration of occupants and unlike in a naturally ventilated hall, $\mathrm{CO}_{2}$ tends to accumulate and increase with the duration of lecture in air-conditioned lecture halls. Based on the results, L02 recorded maximum $\mathrm{CO}_{2}$ concentration in comparison with the other lecture halls. Occupant density recorded in L02 was $0.380 \mathrm{~m}^{-2}$ and had the highest occupant density among five lecture halls considered. The correlational analysis conducted showed a statistically significant strong positive correlation between the occupant density and indoor $\mathrm{CO}_{2}$ levels.

Significant associations between symptoms such as headache, dry throat, difficulties in concentration, cough, and dryness in eye were proven significant for certain lecture halls 
through the ordinal logistic regression. Above results indicate that, air-conditioned lecture halls selected for this study did not provide a favorable indoor environment for the students especially with its design, occupancy control and capacity of the installed air conditioners. Moreover, it is evident that there are significant associations present with the prevalence of SBS symptoms with indoor $\mathrm{CO}_{2}$ concentrations above $1000 \mathrm{ppm}$. In addition, significant variations of $\mathrm{CO}_{2}$ concentrations were observed in back, middle and front of the lecture halls even with the operation of the air conditioners which could be due to the uneven distribution of the occupants and poor air circulation within the lecture hall. RH levels were falling within the recommended range in every lecture hall as the occupants tend to maintain their thermal comfort conditions with the operation of the air conditioners.

Results of the present study shows the importance of maintaining proper occupancy control and better building design practices when designing lecture halls in higher educational facilities. Generally in the building design practice, a high weight is given for the better designing and proper ventilation planning for buildings such as domestic and commercial buildings as people tend to stay longer periods in such buildings. However, higher education students spend prolonged periods in confined lecture halls with high occupancy rates which could lead to the exposure of poor indoor air quality during the course of their study. This study has shown the correlations between SBS symptoms and indoor $\mathrm{CO}_{2}$ levels particularly for air conditioned lecture halls where the air circulation is limited when compared with the naturally ventilated halls. Therefore, the results of this study provide valuable insights on prevalence of SBS on air-conditioned lecture halls, which should be taken into consideration in future lecture hall designing by selecting optimal dimensions, controlling number of occupants and maintaining appropriate capacity of air conditioning within the lecture hall. 


\section{Declarations}

\subsection{Availability of data and materials}

The datasets generated and/or analyzed during the current study are not publicly available due to ethical considerations but are available from the corresponding author on reasonable request.

\subsection{Competing interests}

The authors declare that they have no competing interests.

\subsection{Funding}

Not applicable

\subsection{Authors' contributions}

Conceptualization, Jayasooriya V.M. and Rajapaksha R.M.D.H.; Methodology, Jayasooriya V.M, Ng A.W.M.; Data Collection and Analysis, Rajapaksha R.M.D.H, Jayasooriya V,M; writing - original draft preparation, Jayasooriya V,M, Rajapaksha R.M.D.H; writing - review and editing, Jayasooriya V,M, , Ng, A,W,M, Muthukumaran,.; Supervision, Ng, A,W,M, Muthukumaran, $\mathrm{S}$

\subsection{Acknowledgements}

Not applicable

\subsection{Authors' information (optional)}

\section{References}

Ashrae, 2007. Ventilation for Acceptable Indoor Air Quality 2007, American Society of Heating, Refrigerating and Air-Conditioning Engineers, ANSI/ASHRAE Standard 62.1-2007, Atlanta.

Antoniadou, P. \& Papadopoulos, A. M. 2017. Occupants' thermal comfort: State of the art and the prospects of personalized assessment in office buildings. Energy and Buildings, 153, 136-149.

Apte, M. \& Erdmann, C. 2002. Associations of indoor carbon dioxide concentrations, VOCs, environmental susceptibilities with mucous membrane and lower respiratory sick building syndrome symptoms in the BASE study: Analyses of the 100 building dataset.

Apte, M. G., Fisk, W. J. \& Daisey, J. M. Indoor carbon dioxide concentrations and SBS in office workers. Proceedings of Healthy Buildings, 2000. 133.

Bluyssen, P. M. 2009. Towards an integrative approach of improving indoor air quality. Building and Environment, 44, 1980-1989.

Burge, P. 2004. Sick building syndrome. Occupational and environmental medicine, 61, 185-190.

Chew, B., Kazi, S. \& Amiri, A. 2015. Adaptive thermal comfort model for air-conditioned lecture halls in Malaysia.

Chirico, F., Ferrari, G., Taino, G., Oddone, E., Giorgi, I. \& Imbriani, M. 2017. Prevalence and risk factors for sick building syndrome among Italian correctional officers: a pilot study. J. Health Social Sci, 2, 31-46. 
Corgnati, S. P., Filippi, M. \& Viazzo, S. 2007. Perception of the thermal environment in high school and university classrooms: Subjective preferences and thermal comfort. Building and environment, 42, 951-959.

El Asmar, M., Chokor, A. \& Srour, I. 2014. Are building occupants satisfied with indoor environmental quality of higher education facilities? Energy procedia, 50, 751-760.

Ellis J. 2010, Indoor Air Quality in Lecture Theatres and Large Enclosed Public Spaces, PhD thesis, The University of Brighton.

Emmerich S.J., Persily A.K. 2001, State of aret revie of $\mathrm{CO}_{2}$ demand controlled ventilation technology and application, National institute of Standards and Technology.

Erdmann, C. A. \& Apte, M. G. 2003. Associations of indoor carbon dioxide concentrations and environmental susceptibilities with mucous membrane and lower respiratory building related symptoms in the BASE study: Analyses of the 100 building datas et.

Erdmann, C. A., Steiner, K. C. \& Apte, M. G. 2002. Indoor carbon dioxide concentrations and sick building syndrome symptoms in the BASE study revisited: Analyses of the 100 building dataset.

Ern Jun, K., Hamzah, N. A. \& Anua, S. M. 2017. Indoor Air Quality and Symptoms of Sick Building Syndrome in Two Selected Building (New versus Old).

Fang, Z., Zhang, S., Cheng, Y., Fong, A. M., Oladokun, M. O., Lin, Z. \& Wu, H. 2018. Field study on adaptive thermal comfort in typical air conditioned classrooms. Building and Environment, 133, 73-82.

Fisk, W. J. 2009. Quantitative relationship of sick building syndrome symptoms with ventilation rates.

Fu, C. C., Li, L. \& Lee, A. 2019. A Practical Study on Reducing CO2 Density in Educational Buildings in North-East China. Journal of Construction Research, 65, 65881289.

Ghaffarianhoseini, A., Alwaer, H., Omrany, H., Ghaffarianhoseini, A., Alalouch, C., ClementsCroome, D. \& Tookey, J. 2018. Sick building syndrome: are we doing enough? Architectural Science Review, 61, 99-121.

Gupta, S., Khare, M. \& Goyal, R. 2007. Sick building syndrome-A case study in a multistory centrally air-conditioned building in the Delhi City. Building and Environment, 42, 2797-2809.

Heath, G. \& Mendell, M. Do indoor environments in schools influence student performance? A review of the literature. A Compilation of Papers for the Indoor Air 2002 Conference In Memory of Joan M. Daisey, 2002.

Hedge, A., Erickson, W. A. \& Rubin, G. 1996. Predicting sick building syndrome at the individual and aggregate levels. Environment International, 22, 3-19.

Jones, A. P. 1999. Indoor air quality and health. Atmospheric environment, 33, 4535-4564.

Joshi, S. M. 2008. The sick building syndrome. Indian journal of occupational and environmental medicine, 12, 61.

Katafygiotou, M. C. \& Serghides, D. K. 2014. Thermal comfort of a typical secondary school building in Cyprus. Sustainable Cities and Society, 13, 303-312.

Kraus, M. \& Nováková, P. Assessment of the Indoor Environment for Education. IOP Conference Series: Earth and Environmental Science, 2019. IOP Publishing, 012144.

Licina, D., Bhangar, S. \& Pyke, C. 2019. Occupant health \& well-being in green buildings: Trends and Future Directions.

Lim, F.-L., Hashim, Z., Said, S. M., Than, L. T.-L., Hashim, J. H. \& Norbäck, D. 2015. Sick building syndrome (SBS) among office workers in a Malaysian university-Associations with atopy, fractional exhaled nitric oxide (FeNO) and the office environment. Science of the Total Environment, 536, 353-361.

Mainka, A. \& Zajusz-Zubek, E. 2015. Indoor air quality in urban and rural preschools in upper Silesia, Poland: particulate matter and carbon dioxide. International journal of environmental research and public health, 12, 7697-7711.

Majewski, G., Widziewicz, K., Rogula-Kozłowska, W., Rogula-Kopiec, P., Kociszewska, K., Rozbicki, T., Majder-Łopatka, M. \& Niemczyk, M. 2018. PM origin or exposure duration? Health hazards from PM-bound mercury and PM-bound PAHs among students and lecturers. International journal of environmental research and public health, 15, 316. 
Mentese, S. \& Tasdibi, D. 2016. Airborne bacteria levels in indoor urban environments: The influence of season and prevalence of sick building syndrome (SBS). Indoor and Built Environment, 25, 563-580.

Mihai, T. \& Iordache, V. 2016. Determining the indoor environment quality for an educational building. Energy Procedia, 85, 566-574.

Muhamad-Darus, F., Zain-Ahmed, A. \& Talib, M. 2011. Preliminary assessment of indoor air quality in terrace houses. Health and the Environmental Journal, 2, 8-14.

Mustapa, M. S., Zaki, S. A., Rijal, H. B., Hagishima, A. \& Ali, M. S. M. 2016. Thermal comfort and occupant adaptive behaviour in Japanese university buildings with free running and cooling mode offices during summer. Building and Environment, 105, 332-342.

Nico, M. A., Liuzzi, S. \& Stefanizzi, P. 2015. Evaluation of thermal comfort in university classrooms through objective approach and subjective preference analysis. Applied ergonomics, 48, 111120.

Norbäck, D. \& Nordström, K. 2008. Sick building syndrome in relation to air exchange rate, CO 2, room temperature and relative air humidity in university computer classrooms: an experimental study. International archives of occupational and environmental health, 82, 21-30.

Norhidayah, A., Chia-Kuang, L., Azhar, M. \& Nurulwahida, S. 2013. Indoor air quality and sick building syndrome in three selected buildings. Procedia Engineering, 53, 93-98.

OHAS (2016). Occupational Safety and Health Policy Document 2016-2020. On the road to a safer and healthier culture at work. I. L. Organization.

Oral, G. K., Yener, A. K. \& Bayazit, N. T. 2004. Building envelope design with the objective to ensure thermal, visual and acoustic comfort conditions. Building and Environment, 39, 281-287.

Patnaik, A., Kumar, V. \& Saha, P. 2018. Importance of Indoor Environmental Quality in Green Buildings. Environmental Pollution. Springer.

Pereira, L. D., Raimondo, D., Corgnati, S. P. \& Da Silva, M. G. 2014. Assessment of indoor air quality and thermal comfort in Portuguese secondary classrooms: Methodology and results. Building and Environment, 81, 69-80.

Putra, J. C. P. 2015. Effects of Indoor Air Quality on the Occupant's Health and Productivity in an Office Building. Universiti Tun Hussein Onn Malaysia.

Redlich, C. A., Sparer, J. \& Cullen, M. R. 1997. Sick-building syndrome. The Lancet, 349, 1013-1016.

Ricciardi, P. \& Buratti, C. 2018. Environmental quality of university classrooms: Subjective and objective evaluation of the thermal, acoustic, and lighting comfort conditions. Building and Environment, 127, 23-36.

Scheff, P. A., Paulius, V. K., Huang, S. W. \& Conroy, L. M. 2000. Indoor air quality in a middle school, Part I: Use of $\mathrm{CO} 2$ as a tracer for effective ventilation. Applied occupational and environmental hygiene, 15, 824-834.

Seppänen, O., Fisk, W. \& Mendell, M. 1999. Association of ventilation rates and CO2 concentrations with health andother responses in commercial and institutional buildings. Indoor air, 9, 226252.

Seppanen, O. A. \& Fisk, W. J. 2004. Summary of human responses to ventilation.

Shahzad, S., Brennan, J., Theodossopoulos, D., Hughes, B. \& Calautit, J. 2016. Building-related symptoms, energy, and thermal control in the workplace: personal and open plan offices. Sustainability, 8, 331.

Shin, D. S., Jeong, B. Y. \& Park, M. H. 2018. Structural equation modeling of office environment quality, sick building syndrome, and musculoskeletal complaints on aggregate satisfaction of office workers. Human Factors and Ergonomics in Manufacturing \& Service Industries, 28, 148-153.

Skov, P., Valbjørn, O. \& Pedersen, B. V. 1990. Influence of indoor climate on the sick building syndrome in an office environment. Scandinavian journal of work, environment \& health, 16, 363-371.

Sun, Y., Hou, J., Cheng, R., Sheng, Y., Zhang, X. \& Sundell, J. 2019. Indoor air quality, ventilation and their associations with sick building syndrome in Chinese homes. Energy and Buildings, 197, $112-119$.

Szumilas, M. 2010. Explaining odds ratios. Journal of the Canadian academy of child and adolescent psychiatry, 19, 227. 
Tsai, D.-H., Lin, J.-S. \& Chan, C.-C. 2012. Office workers' sick building syndrome and indoor carbon dioxide concentrations. Journal of occupational and environmental hygiene, 9, 345-351.

Vilčeková, S., Kapalo, P., Mečiarová, L'., Burdová, E. K. \& Imreczeová, V. 2017. Investigation of Indoor Environment Quality in Classroom-Case Study. Procedia engineering, 190, 496-503.

Wijerathne, H., Karunasena, G. \& Mallawaarachchi, B. 2019. Study on sick building syndrome in office environment.

Yang, W., Sohn, J., Kim, J., Son, B. \& Park, J. 2009. Indoor air quality investigation according to age of the school buildings in Korea. Journal of Environmental Management, 90, 348-354.

Yatim, F. 2002. Sickbuilding Syndrome, Building Related Illness Dan Legionellosis: Penyakit Akibat Lingkungan Tempat Kerja Yang Kurang Mendukung. Media Penelitian dan Pengembangan Kesehatan, 12.

Zaki, S. A., Damiati, S. A., Rijal, H. B., Hagishima, A. \& Razak, A. A. 2017. Adaptive thermal comfort in university classrooms in Malaysia and Japan. Building and Environment, 122, 294-306.

Zamani, M. E., Jalaludin, J. \& Shaharom, N. 2013. Indoor air quality and prevalence of sick building syndrome among office workers in two different offices in Selangor. American Journal of Applied Sciences, 10, 1140. 


\section{$\underline{\text { List of Figures }}$}
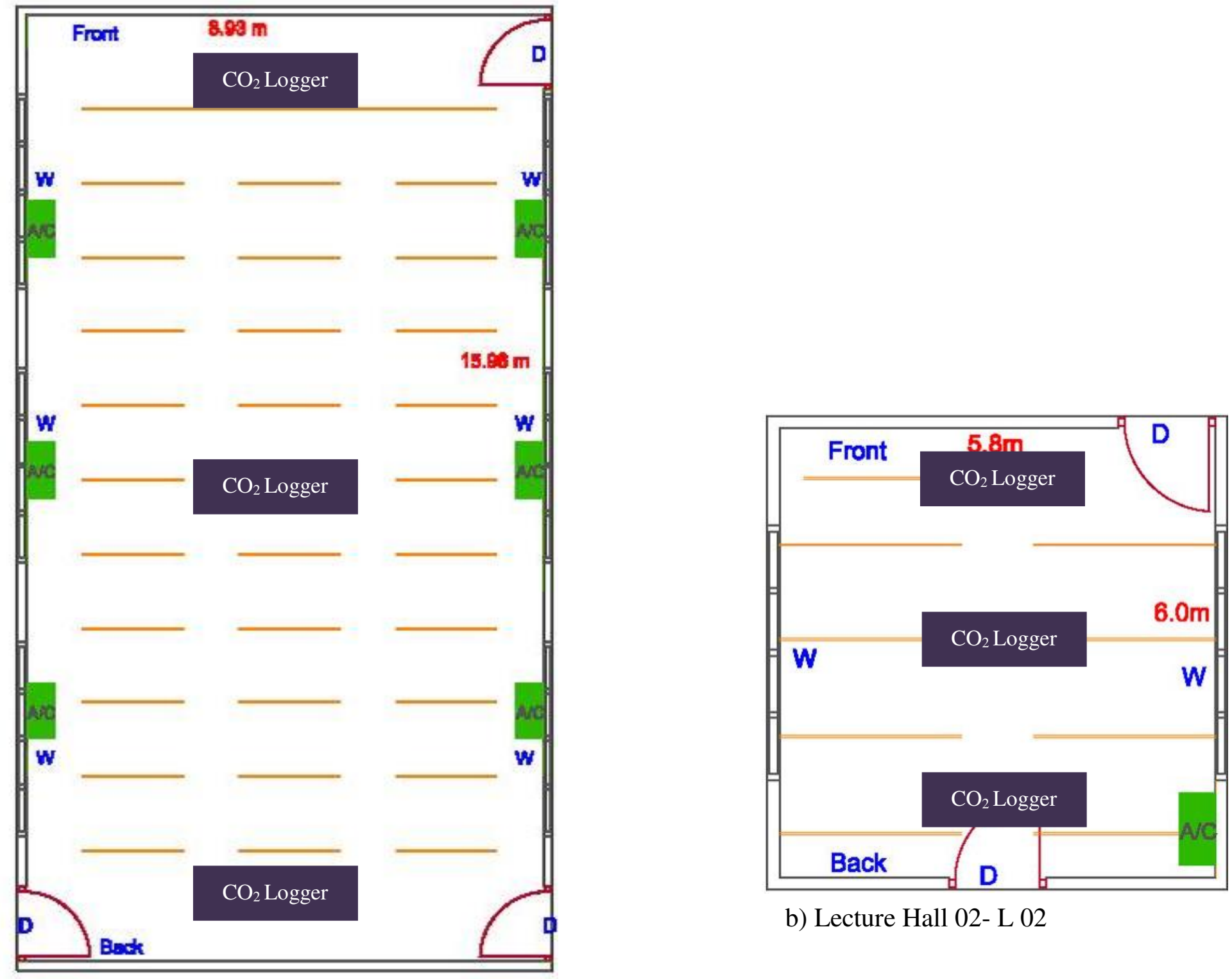

b) Lecture Hall 02- L 02

a) Lecture Hall 01- L 01 


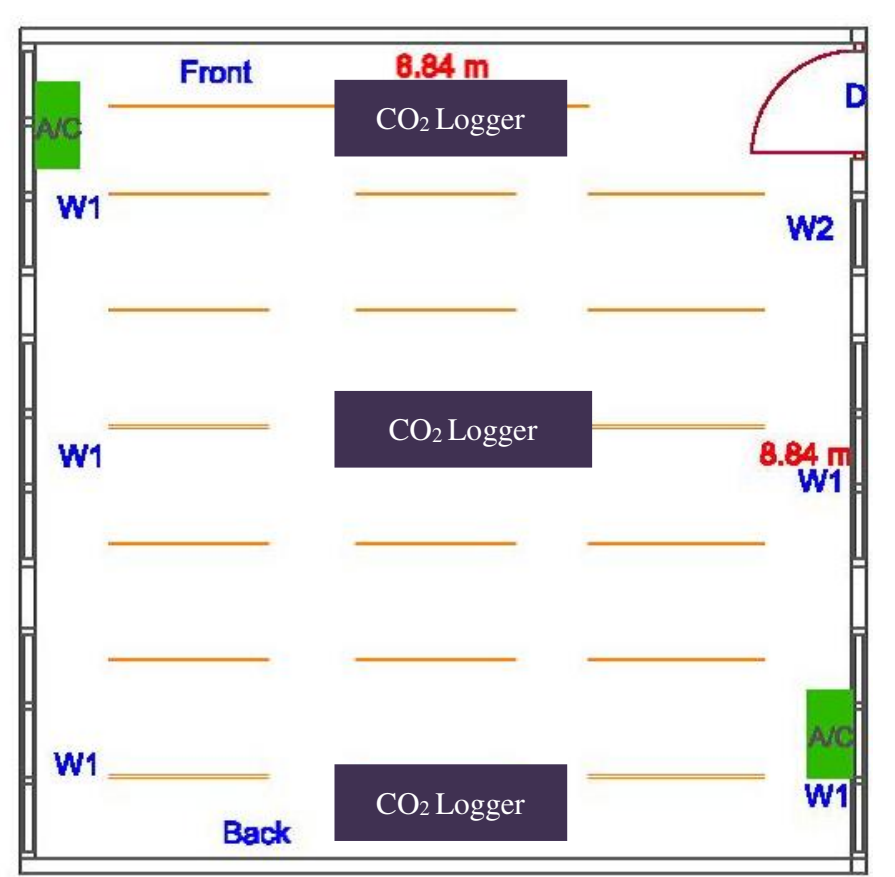

c) Lecture Hall 03- L 03
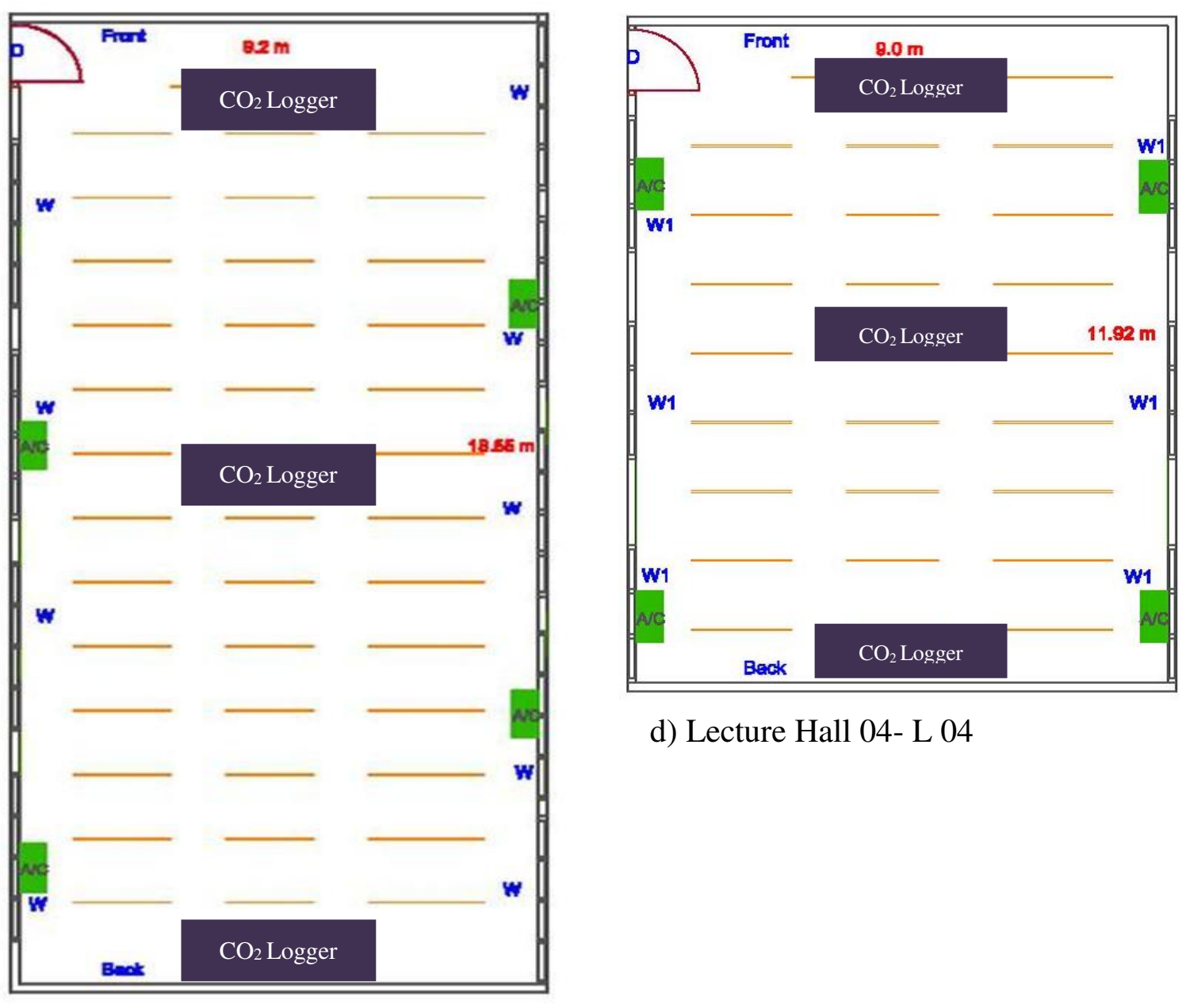

d) Lecture Hall 04- L 04

e) Lecture Hall 05- L 05

Figure 1: Dimensions of selected lecture halls 
800

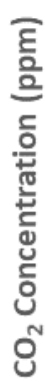

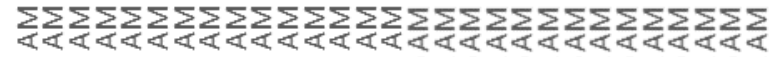

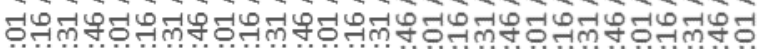
бंб

Time (hh:mm:ss) ठ์
800

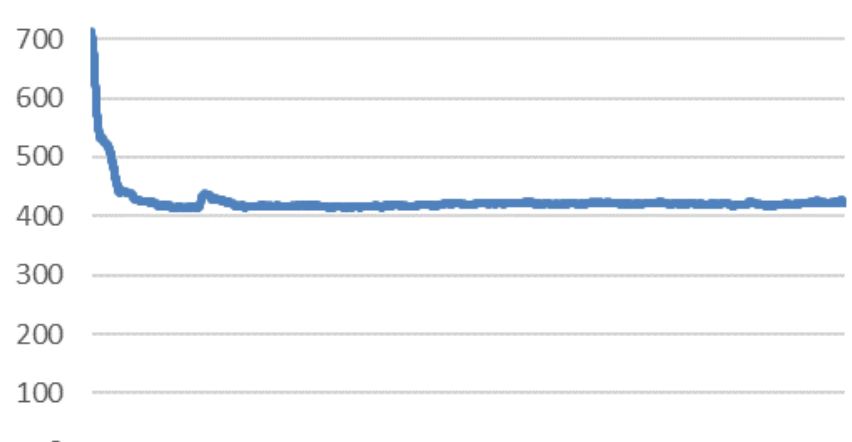

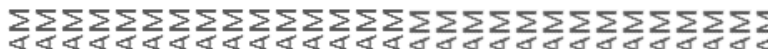
ठัฒ

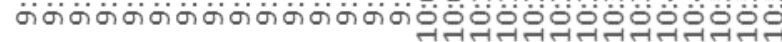

Time (hh:mm:ss)
800

700

600

500

300

200

100

$\sum_{<} \sum_{<} \sum_{<} \sum_{<} \sum_{<} \sum_{<} \sum_{<} \sum_{<} \sum_{<} \sum_{<} \sum_{<} \sum_{<} \sum_{<} \sum_{<} \sum_{<} \sum_{<} \sum_{<} \sum_{<} \sum_{<} \sum_{<} \sum_{<} \sum_{<} \sum_{<} \sum_{<} \sum_{<} \sum_{<} \sum_{<} \sum_{<} \sum_{<}$

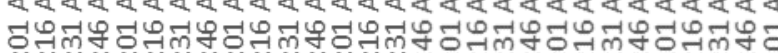
๑ษ்

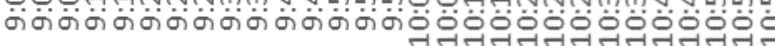

Time (hh:mm:ss)

a) Indoor $\mathrm{CO}_{2}$ Concentrations during the control experiment
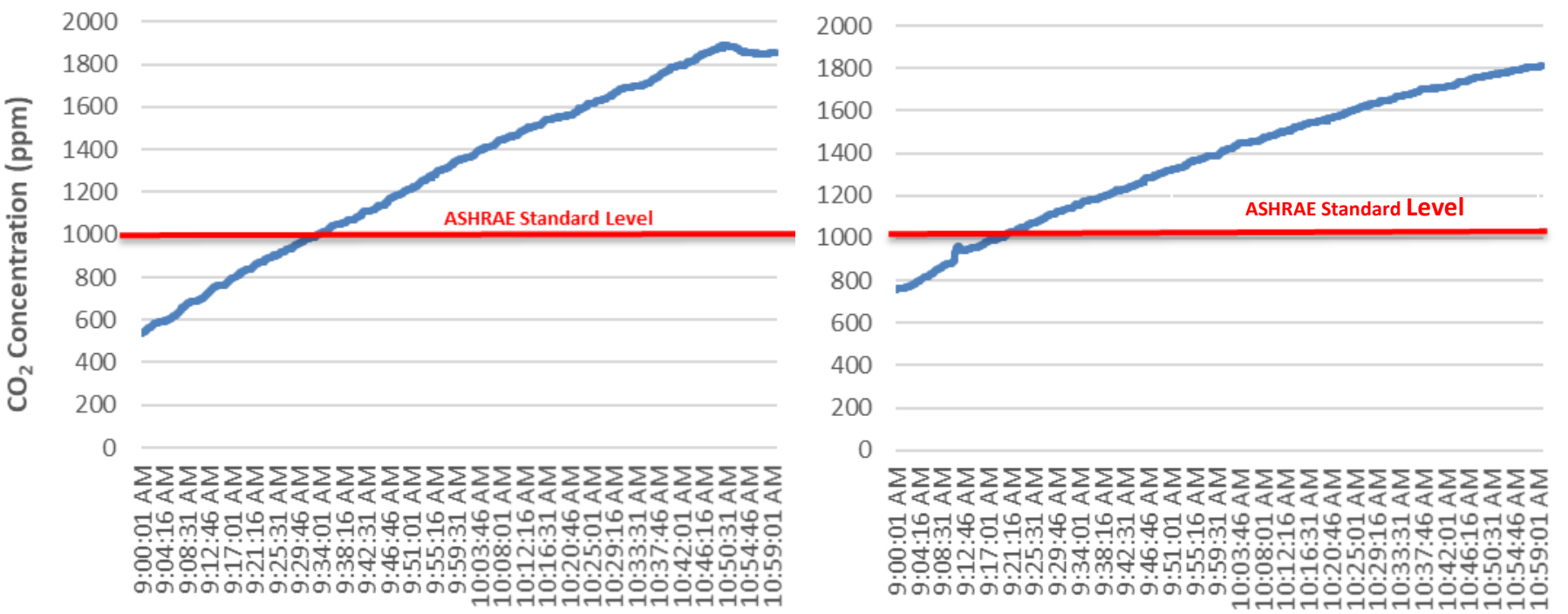

Time (hh:mm:ss)

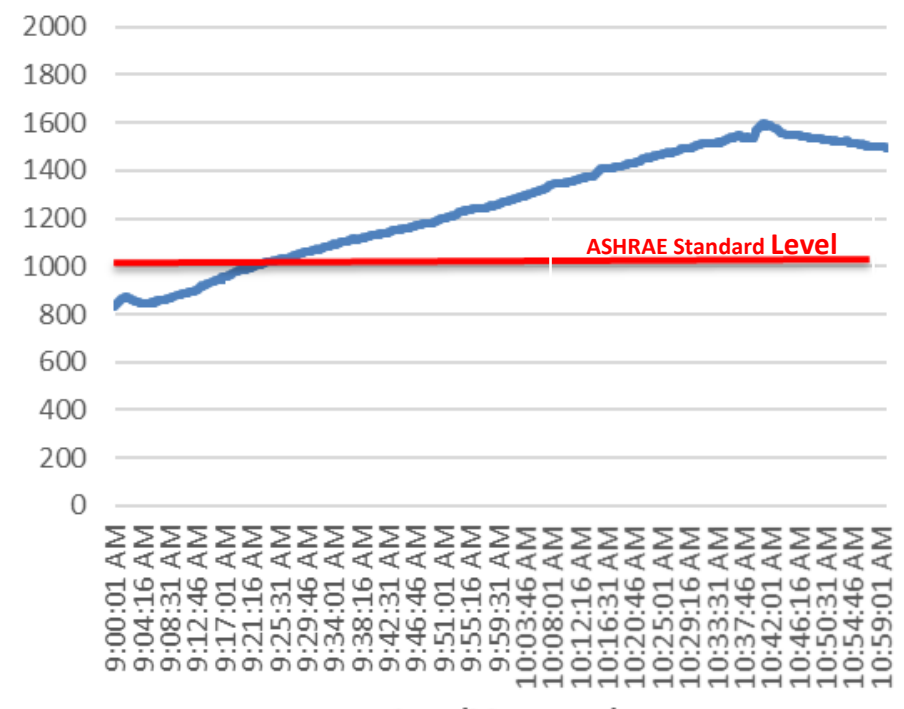

Time (hh:mm:ss)

b) Indoor $\mathrm{CO}_{2}$ concentrations during lecture

Figure 2: Indoor $\mathrm{CO}_{2}$ concentrations for Lecture Hall 01 during the control experiment and the lecture 

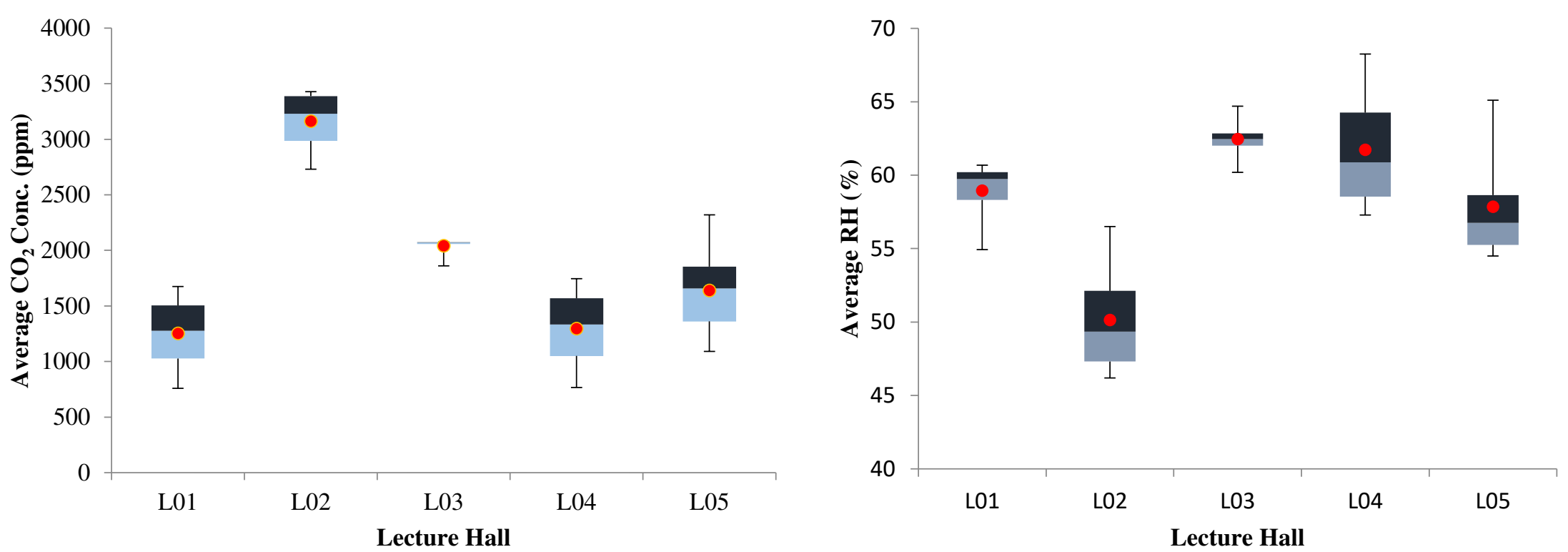

Figure 3: Box and whiskers plots for average $\mathrm{CO}_{2}$ concentration and $\mathrm{RH}$ in 5 lecture halls. 


\section{List of Tables}

Table 1: Average values for the measured IAQ parameters for 5 lecture halls

\begin{tabular}{|c|c|c|c|c|c|c|c|c|c|}
\hline \multirow{2}{*}{$\begin{array}{c}\text { Lecture } \\
\text { hall }\end{array}$} & \multirow{2}{*}{ Parameter } & \multicolumn{8}{|c|}{15 Minute moving averages for two hour time duration } \\
\hline & & 1 & 2 & 3 & 4 & 5 & 6 & 7 & 8 \\
\hline \multirow{3}{*}{ L01 } & $\mathrm{CO}_{2}$ Conc.(ppm) & 759.14 & 917.39 & 1063.12 & 1205.31 & 1347.48 & 1475.18 & 1590.78 & 1675.22 \\
\hline & RH (\%) & 54.93 & 57.42 & 58.61 & 59.38 & 60.19 & 60.21 & 60.10 & 60.68 \\
\hline & Temperature $\left({ }^{\circ} \mathrm{C}\right)$ & 26.48 & 26.01 & 25.82 & 25.84 & 25.90 & 25.96 & 25.95 & 25.98 \\
\hline \multirow{4}{*}{ L02 } & $\mathrm{CO}_{2}$ Conc. $(\mathrm{ppm})$ & 2730.62 & 2881.58 & 3019.39 & 3172.20 & 3287.51 & 3382.71 & 3406.90 & 3428.15 \\
\hline & $\mathrm{RH}(\%)$ & 56.50 & 54.41 & 51.36 & 50.08 & 48.60 & 47.65 & 46.19 & 46.30 \\
\hline & Temperature & 28.35 & 27.99 & 27.71 & 27.52 & 27.31 & 27.21 & 27.03 & 27.02 \\
\hline & $\left({ }^{\circ} \mathrm{C}\right)$ & & & & & & & & \\
\hline \multirow{4}{*}{ L03 } & $\mathrm{CO}_{2}$ Conc. $(\mathrm{ppm})$ & 2075.67 & 2071.27 & 2075.05 & 2074.58 & 2068.17 & 2062.65 & 2037.85 & 1860.75 \\
\hline & RH (\%) & 64.70 & 62.50 & 61.96 & 62.03 & 62.40 & 62.71 & 63.20 & 60.20 \\
\hline & Temperature & 31.07 & 31.95 & 32.13 & 32.09 & 32.01 & 31.89 & 31.81 & 30.85 \\
\hline & $\left({ }^{\circ} \mathrm{C}\right)$ & & & & & & & & \\
\hline \multirow{4}{*}{ L04 } & $\mathrm{CO}_{2}$ Conc. $(\mathrm{ppm})$ & 766.39 & 899.99 & 1100.60 & 1259.24 & 1407.25 & 1542.43 & 1652.29 & 1745.49 \\
\hline & RH $(\%)$ & 68.25 & 66.36 & 63.57 & 61.46 & 60.29 & 58.79 & 57.79 & 57.29 \\
\hline & Temperature & 28.76 & 28.62 & 28.38 & 28.11 & 27.93 & 27.78 & 27.66 & 27.59 \\
\hline & $\left({ }^{\circ} \mathrm{C}\right)$ & & & & & & & & \\
\hline \multirow{4}{*}{ L05 } & $\mathrm{CO}_{2}$ Conc. $(\mathrm{ppm})$ & 1091.22 & 1213.05 & 1410.93 & 1577.31 & 1738.95 & 1824.69 & 1941.99 & 2319.83 \\
\hline & $\mathrm{RH}(\%)$ & 65.11 & 61.82 & 57.59 & 56.54 & 55.40 & 54.50 & 56.98 & 54.83 \\
\hline & Temperature & 29.08 & 28.96 & 28.48 & 28.50 & 28.46 & 27.85 & 27.83 & 27.90 \\
\hline & $\left({ }^{\circ} \mathrm{C}\right)$ & & & & & & & & \\
\hline
\end{tabular}


Table 2: Summary statistics for the measured IAQ parameters in lecture halls

\begin{tabular}{|c|c|c|c|c|}
\hline Lecture hall & Variable & Mean & SD & Range \\
\hline \multirow{3}{*}{ L01 } & $\mathrm{CO}_{2}$ Conc.(ppm) & 1254 & 326 & $1675-759$ \\
\hline & $\mathrm{RH}(\%)$ & 58.941 & 1.937 & $60.682-54.932$ \\
\hline & Temperature $\left({ }^{\circ} \mathrm{C}\right)$ & 25.993 & 0.207 & $26.478-25.825$ \\
\hline \multirow{3}{*}{ L02 } & $\mathrm{CO}_{2}$ Conc. $(\mathrm{ppm})$ & 3163.6 & 262 & $3428.2-2730.6$ \\
\hline & RH (\%) & 50.14 & 3.76 & $56.5-46.19$ \\
\hline & Temperature $\left({ }^{\circ} \mathrm{C}\right)$ & 27.518 & 0.475 & $28.346-27.018$ \\
\hline \multirow{3}{*}{ L03 } & $\mathrm{CO}_{2}$ Conc.(ppm) & 2040.7 & 73.8 & $2075.7-1860.8$ \\
\hline & RH (\%) & 62.463 & 1.264 & $64.7-60.2$ \\
\hline & Temperature $\left({ }^{\circ} \mathrm{C}\right)$ & 31.725 & 0.487 & $32.13-30.85$ \\
\hline \multirow{3}{*}{ L04 } & $\mathrm{CO}_{2}$ Conc. $(\mathrm{ppm})$ & 1297 & 354 & $1745-766$ \\
\hline & $\mathrm{RH}(\%)$ & 61.73 & 4.02 & $68.25-57.29$ \\
\hline & Temperature $\left({ }^{\circ} \mathrm{C}\right)$ & 28.104 & 0.442 & $28.76-27.59$ \\
\hline \multirow{3}{*}{ L05 } & $\mathrm{CO}_{2}$ Conc. (ppm) & 1640 & 403 & $2320-1091$ \\
\hline & RH (\%) & 57.85 & 3.73 & $65.11-54.50$ \\
\hline & Temperature $\left({ }^{\circ} \mathrm{C}\right)$ & 28.383 & 0.489 & $29.08-27.83$ \\
\hline
\end{tabular}


Table 3: Outdoor $\mathrm{CO}_{2}$ levels, $\mathrm{RH}$ and Temperature values

\begin{tabular}{|c|c|c|c|c|c|c|c|c|c|}
\hline \multirow{2}{*}{$\begin{array}{c}\text { Lecture } \\
\text { hall }\end{array}$} & \multirow{2}{*}{ Parameter } & \multicolumn{8}{|c|}{15 Minute moving averages for two hour time duration } \\
\hline & & 1 & 2 & 3 & 4 & 5 & 6 & 7 & 8 \\
\hline \multirow{3}{*}{$\begin{array}{l}\text { L01 and } \\
\text { L02 }\end{array}$} & $\mathrm{CO}_{2}$ Conc.(ppm) & 433.77 & 428.57 & 430.60 & 421.12 & 424.74 & 424.13 & 427.20 & 434.47 \\
\hline & $\mathrm{RH}(\%)$ & 69.23 & 68.60 & 69.30 & 68.06 & 67.90 & 68.19 & 67.34 & 66.17 \\
\hline & Temperature $\left({ }^{\circ} \mathrm{C}\right)$ & 31.53 & 31.52 & 31.42 & 31.76 & 31.76 & 31.76 & 32.07 & 32.38 \\
\hline \multirow{3}{*}{$\begin{array}{c}\text { L03 and } \\
\text { L04 }\end{array}$} & $\mathrm{CO}_{2}$ Conc.(ppm) & 445.99 & 442.17 & 436.20 & 446.09 & 443.97 & 442.66 & 442.89 & 443.06 \\
\hline & $\mathrm{RH}(\%)$ & 74.55 & 72.22 & 70.81 & 70.27 & 71.78 & 72.58 & 71.64 & 70.95 \\
\hline & Temperature $\left({ }^{\circ} \mathrm{C}\right)$ & 30.58 & 31.38 & 31.55 & 31.76 & 31.73 & 31.59 & 31.73 & 31.73 \\
\hline \multirow{3}{*}{ L05 } & $\mathrm{CO}_{2}$ Conc. $(\mathrm{ppm})$ & 446.03 & 442.11 & 435.89 & 446.23 & 444.09 & 442.52 & 443.01 & 443.02 \\
\hline & $\mathrm{RH}(\%)$ & 74.90 & 75.52 & 75.78 & 75.33 & 75.17 & 75.38 & 75.34 & 75.20 \\
\hline & Temperature $\left({ }^{\circ} \mathrm{C}\right)$ & 29.59 & 29.31 & 29.55 & 29.88 & 29.92 & 29.91 & 29.88 & 29.84 \\
\hline
\end{tabular}


Table 4: Summary results for the ordinal logistic regression for 5 lecture halls

\begin{tabular}{|c|c|c|c|c|c|c|c|c|c|c|c|c|c|c|c|c|c|c|c|c|}
\hline \multirow[b]{5}{*}{ Symptom } & \multicolumn{4}{|c|}{ L01 } & \multicolumn{4}{|c|}{ L02 } & \multicolumn{4}{|c|}{ L03 } & \multicolumn{4}{|c|}{ L04 } & \multicolumn{4}{|c|}{ L05 } \\
\hline & \multirow{4}{*}{$\begin{array}{l}\text { Signi } \\
\text { fican } \\
\text { ce }\end{array}$} & \multirow{3}{*}{\multicolumn{2}{|c|}{$\begin{array}{c}95 \% \\
\text { Confidence } \\
\text { Interval }\end{array}$}} & \multirow[b]{4}{*}{$\begin{array}{l}\text { Odds } \\
\text { Ratio } \\
\end{array}$} & \multirow{3}{*}{\multicolumn{3}{|c|}{$\begin{array}{c}95 \% \\
\text { Confidence } \\
\text { Interval }\end{array}$}} & \multirow[b]{4}{*}{$\begin{array}{l}\text { Odds } \\
\text { Ratio } \\
\end{array}$} & \multirow{3}{*}{\multicolumn{3}{|c|}{$\begin{array}{c}95 \% \\
\text { Confidence } \\
\text { Interval }\end{array}$}} & \multirow[b]{4}{*}{$\begin{array}{l}\text { Odds } \\
\text { Ratio } \\
\end{array}$} & \multirow{2}{*}{\multicolumn{4}{|c|}{$\begin{array}{c}95 \% \\
\text { Confider }\end{array}$}} & \multirow{3}{*}{\multicolumn{3}{|c|}{$\begin{array}{l}\text { 95\% Confidence } \\
\text { Interval }\end{array}$}} & \multirow[b]{4}{*}{$\begin{array}{l}\text { Odds } \\
\text { Ratio } \\
\end{array}$} \\
\hline & & & & & & & & & & & & & & & & & & & & \\
\hline & & & & & & & & & & & & & Signi & Int & val & & & & & \\
\hline & & $\begin{array}{l}\text { Lower } \\
\text { Bound }\end{array}$ & $\begin{array}{l}\text { Upper } \\
\text { Bound }\end{array}$ & & $\begin{array}{l}\text { fican } \\
\text { ce }\end{array}$ & $\begin{array}{l}\text { Lower } \\
\text { Bound }\end{array}$ & $\begin{array}{l}\text { Upper } \\
\text { Bound }\end{array}$ & & $\begin{array}{l}\text { fican } \\
\text { ce }\end{array}$ & $\begin{array}{l}\text { Lower } \\
\text { Bound }\end{array}$ & $\begin{array}{l}\text { Upper } \\
\text { Bound }\end{array}$ & & $\begin{array}{l}\text { fican } \\
\text { ce }\end{array}$ & $\begin{array}{l}\text { Lower } \\
\text { Bound }\end{array}$ & $\begin{array}{l}\text { Upper } \\
\text { Bound }\end{array}$ & $\begin{array}{l}\text { Odds } \\
\text { Ratio }\end{array}$ & $\begin{array}{l}\text { fican } \\
\text { ce }\end{array}$ & $\begin{array}{l}\text { Lower } \\
\text { Bound }\end{array}$ & $\begin{array}{l}\text { Upper } \\
\text { Bound }\end{array}$ & \\
\hline $\begin{array}{l}\text { Blocked or } \\
\text { stuffy nose }\end{array}$ & .043 & 0 & 1 & 1.999 & .010 & 0 & 2 & 2.598 & .223 & 0 & 1 & 1.625 & .761 & -1 & 1 & 1.164 & .002 & 0 & 2 & 3.254 \\
\hline Cough & .843 & -1 & 1 & 1.071 & .001 & 1 & 2 & $3.524 *$ & .450 & 0 & 1 & 1.354 & .618 & -1 & 1 & 1.280 & .128 & 0 & 1 & 1.812 \\
\hline $\begin{array}{l}\text { Difficulties } \\
\text { in } \\
\text { concentrati } \\
\text { on }\end{array}$ & .000 & 1 & 2 & $3.431^{*}$ & .007 & 0 & 2 & 2.710 & .000 & 1 & 2 & $5.240 *$ & .021 & 0 & 2 & 3.008 & .003 & 0 & 2 & 3.078 \\
\hline Dry throat & .398 & 0 & 1 & 1.338 & .029 & 0 & 2 & 2.264 & .000 & 1 & 2 & $5.169 *$ & .192 & 0 & 2 & 1.880 & .000 & 1 & 2 & $3.847 *$ \\
\hline $\begin{array}{l}\text { Dry/Itchin } \\
\text { g/ Irritated } \\
\text { skin }\end{array}$ & .784 & -1 & 1 & 1.100 & .041 & 0 & 1 & 2.143 & .141 & -2 & 0 & 0.521 & .116 & -2 & 0 & 0.401 & .616 & -1 & 1 & 1.225 \\
\hline $\begin{array}{l}\text { Dryness in } \\
\text { the eye }\end{array}$ & .458 & 0 & 1 & 1.292 & .383 & 0 & 1 & 1.393 & .004 & 0 & 2 & 3.076 & .448 & -1 & 1 & 1.451 & .058 & 0 & 1 & 2.079 \\
\hline $\begin{array}{l}\text { Fatigue/let } \\
\text { hargy/tired } \\
\text { ness }\end{array}$ & .092 & 0 & 1 & 1.783 & .181 & 0 & 1 & 1.655 & .000 & 2 & 3 & $10.48 *$ & .102 & 0 & 2 & 2.197 & .002 & 0 & 2 & 3.223 \\
\hline Headache & .000 & 1 & 2 & $3.729^{*}$ & .000 & 1 & 2 & $3.743 *$ & .000 & 1 & 2 & $4.104 *$ & .143 & 0 & 2 & 2.029 & .002 & 0 & 2 & 3.296 \\
\hline $\begin{array}{l}\text { Heavy } \\
\text { headed }\end{array}$ & .049 & 0 & 1 & 1.966 & .034 & 0 & 2 & 2.205 & .006 & 0 & 2 & 2.962 & .462 & -1 & 1 & 1.435 & .068 & 0 & 1 & 2.026 \\
\hline $\begin{array}{l}\text { Itchy or } \\
\text { watery eye }\end{array}$ & .092 & -1 & 0 & 0.544 & .856 & -1 & 1 & 0.932 & .338 & 0 & 1 & 1.467 & .434 & -1 & 1 & 0.659 & .809 & -1 & 1 & 1.104 \\
\hline
\end{tabular}

"Indicates statistically significant odds ratio, (CI) $>1$ and $\mathrm{OR}>1$ at $95 \%$ confidence interval 
Table 5: Summary results of the significant SBS symptoms

\begin{tabular}{lrrrrl}
\hline Lecture hall & $\begin{array}{l}\text { Floor Area } \\
\left(\mathbf{m}^{2}\right)\end{array}$ & $\begin{array}{l}\text { Average Occupant } \\
\text { Density (per square } \\
\text { meter) }\end{array}$ & $\begin{array}{l}\mathbf{d C O}_{2} \\
(\mathbf{p p m})\end{array}$ & dRH (\%) & Statistically Significant Symptoms reported \\
\hline L01 (n=30) & 142.52 & 0.208 & 1240.76 & 8.62 & Difficulties in concentration, Headache \\
L02 (n=13) & 34.8 & 0.383 & 2993.69 & 12.80 & Cough, Headache \\
L03 (n=14) & 78.15 & 0.176 & 1629.58 & 9.85 & Difficulties in concentration, dry throat, fatigue/lethargy/tiredness \\
& 107.28 & 0.207 & 1299.40 & 6.30 & No statistically significant symptoms \\
L04 (n=22) & 170.66 & 0.278 & 1873.60 & 10.67 & Dry throat \\
L05 (n=47) & & & & & \\
\hline
\end{tabular}


Figures

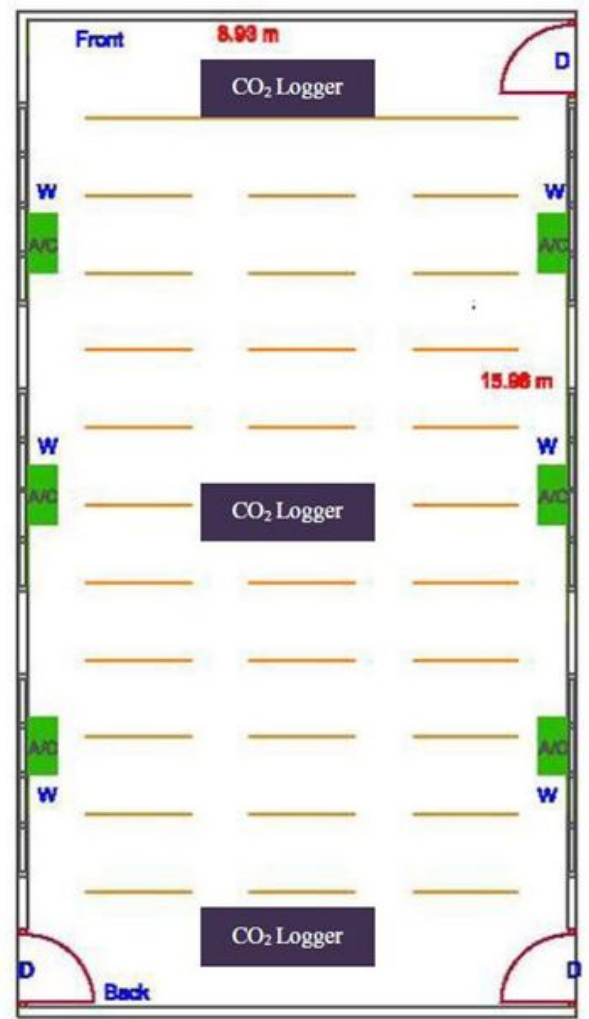

a) Lecture Hall 01- L 01

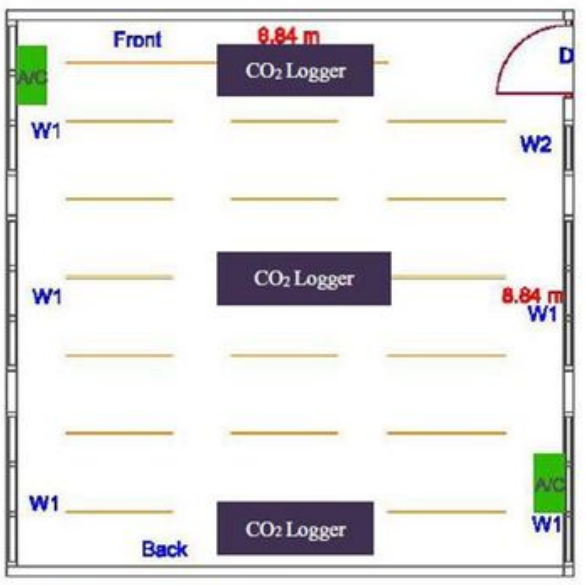

c) Lecture Hall 03- L 03

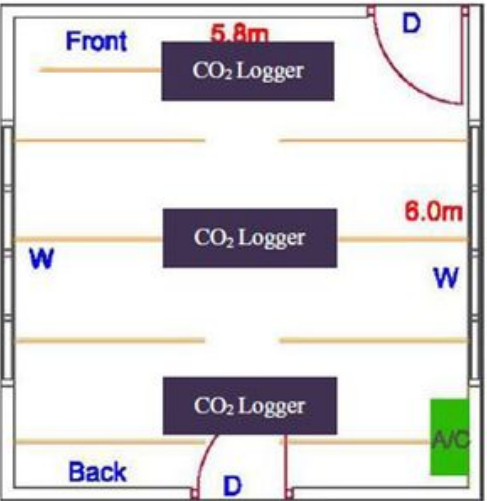

b) Lecture Hall 02- L 02

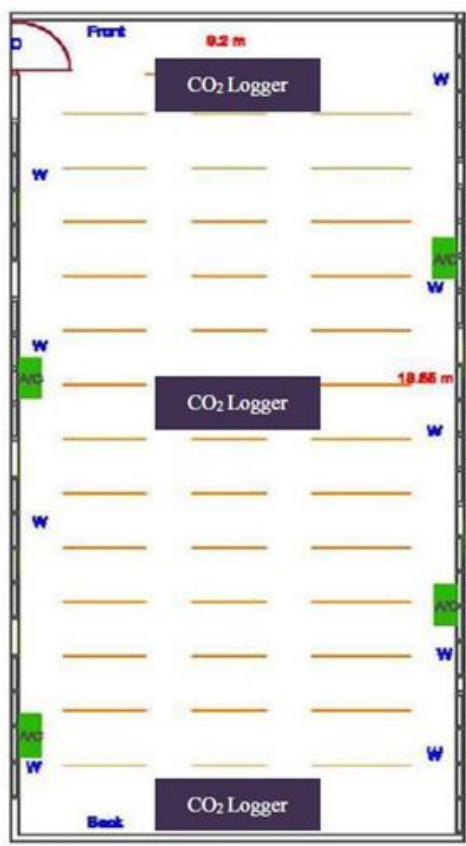

e) Lecture Hall 05- L 05

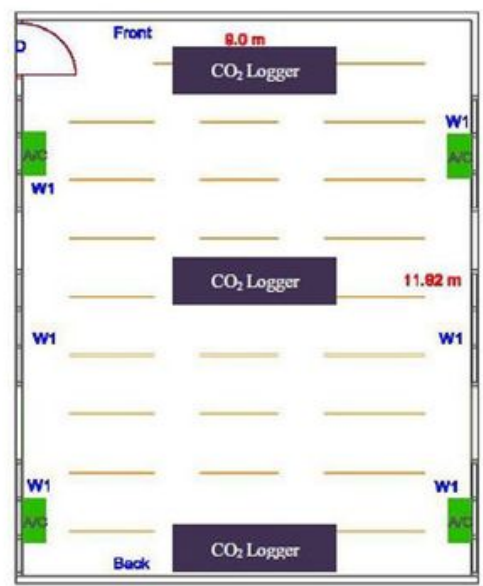

d) Lecture Hall 04- L 04

\section{Figure 1}

Dimensions of selected lecture halls 
L01 - Front

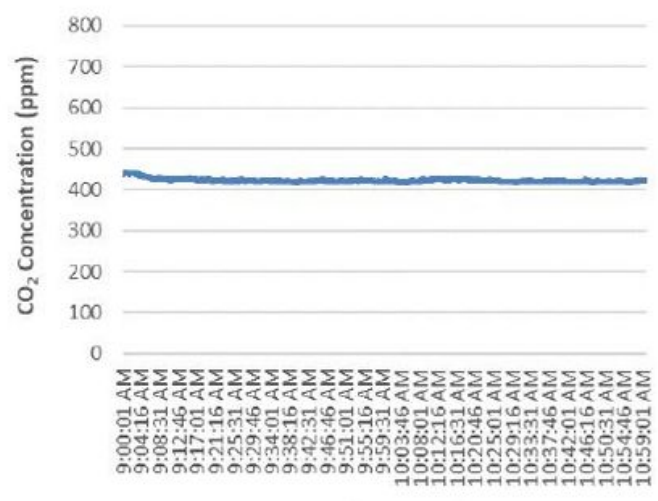

Time (hh:mm:ss)
L01 - Middle

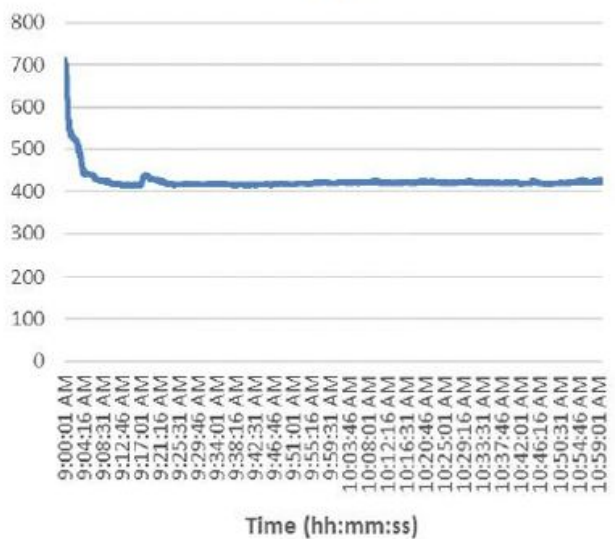

L01 - Back

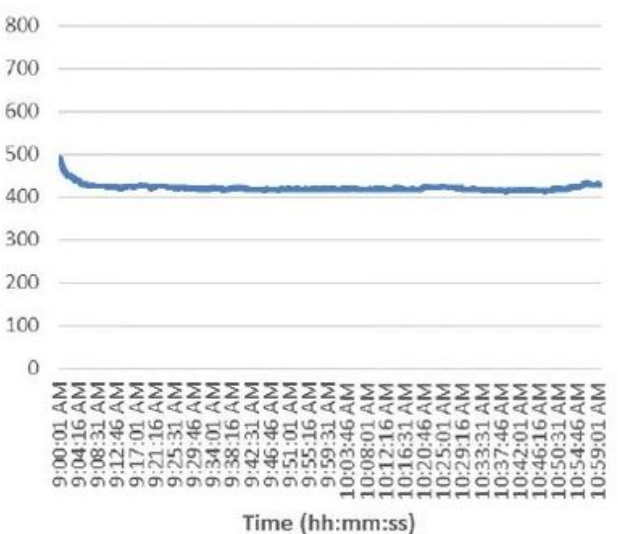

a) Indoor $\mathrm{CO}_{2}$ Concentrations during the control experiment
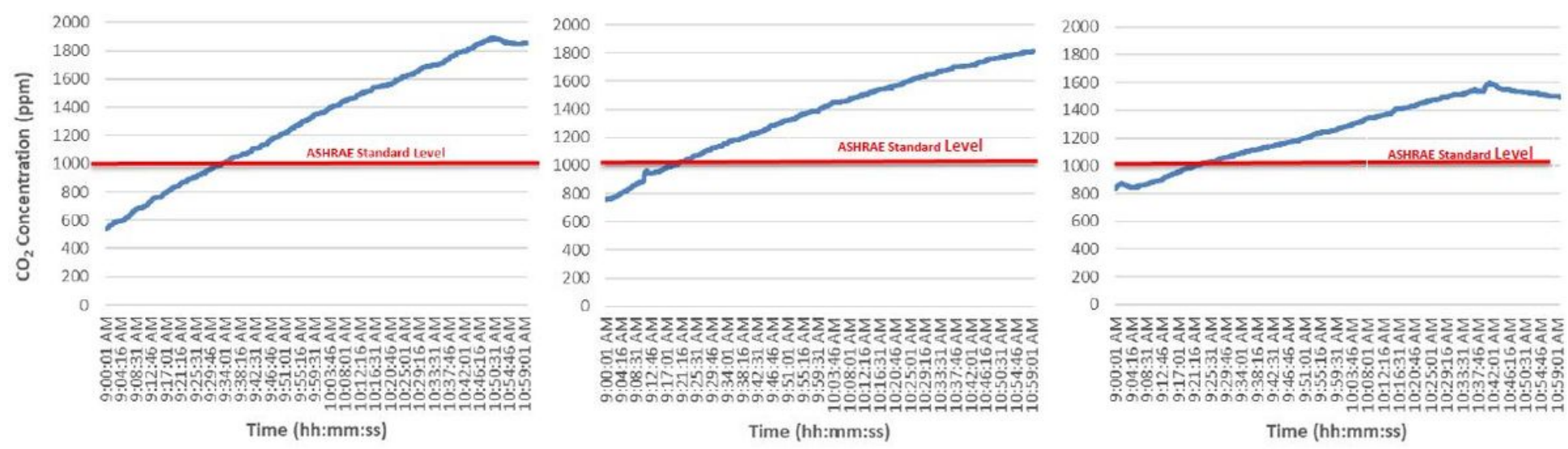

b) Indoor $\mathrm{CO}_{2}$ concentrations during lecture

\section{Figure 2}

Indoor $\mathrm{CO} 2$ concentrations for Lecture Hall 01 during the control experiment and the lecture
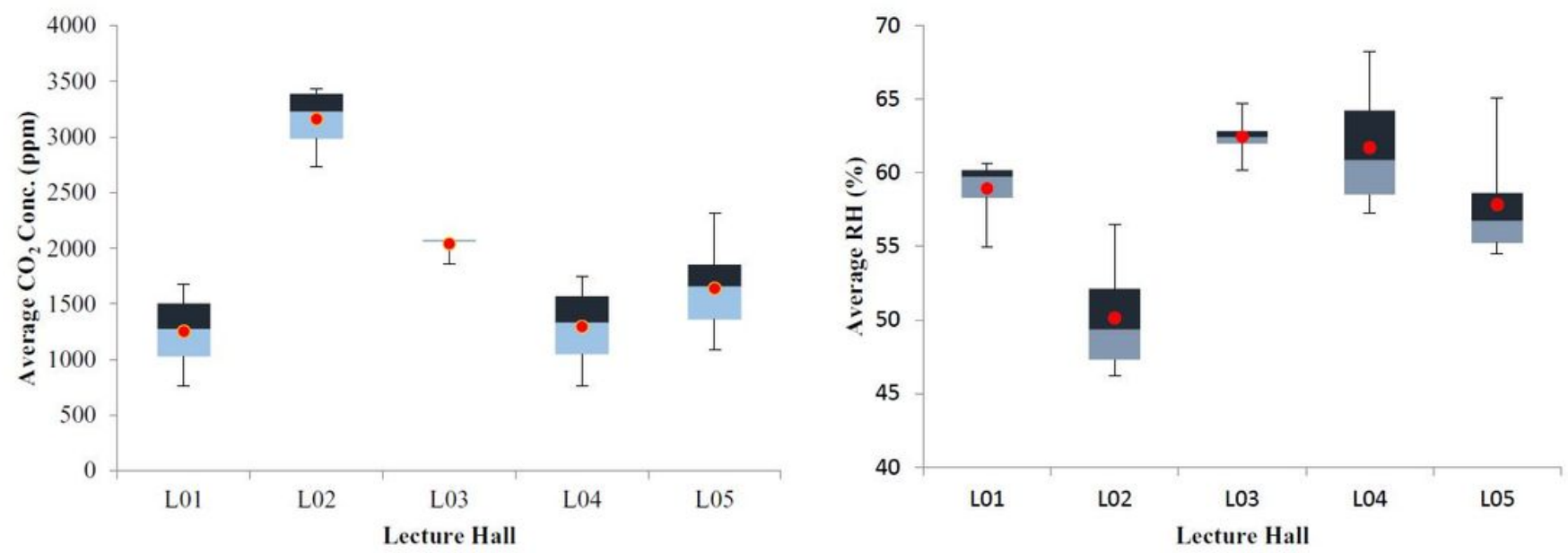

Figure 3 
Box and whiskers plots for average $\mathrm{CO} 2$ concentration and $\mathrm{RH}$ in 5 lecture halls. 